\title{
At the crossroads
}

\section{Dixit $\mathrm{H}$}

Hemang Dixit, Head of Department of Medical Education, Kathmandu Medical College, Kathmandu, Nepal

T The country is at the crossroads with the amendment of the constitution. The medical education system for the production of health manpower has been in a similar state for a long time. Of course, disease has existed since time immemorial and we must take note that Arogyashalas existed in Nepal at the time of Amshu Verma in the 7th Century. There surely were some trained personnel to run these.

The western form of medical education in Nepal started in 1928 when a Dr. Krishna Raj Mukerjee was appointed as the head of an institution named Nepal Medical College. What category of personnel it produced is yet to be identified but what Dr. Mukerjee did do was to give a public display of dissection of the human body. Over the subsequent years, a number of institutions for the training of manpower for health came up within the country in the order given below':

- Nepal Rajkiya Ayurved Vidyalaya - 1933/34

- Civil Medical School-1934

- Nursing School (Bir Hospital) - 1956

- Health Assistants (Ministry of Health) at Bir Hospital $-1956$

- Auxilliary Health Worker School (Ministry of Health) 1962

- Auxillary Nurse Midwifery School - 1968 (Hetauda, later to Bharatpur)

- Institute of Medicine, New Education System Plan, under Ministry of Education- 1972

The task of setting up the teaching for the different categories of health manpower was first under the Ministry of Health (MoH) and then in 1972, came under the Ministry of Education. Following the various student unrests in 1979 (2036 BS), a Royal Commission

Address for correspondence

Dr. Hemang Dixit

Head of Department of Medical Education

Kathmandu Medical College Teaching Hospital

Sinamangal, Kathmandu, Nepal

E-mail:h2dixit@gmail.com was formed under Prof. Surya Bahadur Shakya with the thought of making a separate technical university catering to science subjects. It did not come to pass, though some autonomy was granted to the Institute of Medicine (IOM) which persists to this day. Some functions, like the conduction of examinations, have been given, but IOM has still to be given authority to work with full autonomy as Tribhuvan University (TU). As the university derives much benefit from this linkage, it does not want to cut the umbilical cord that gives much health care benefits to the students, faculty and staff of TU.

The formation of the BP Koirala Institute of Health Sciences - a deemed university at Dharan, with all its programmes for different grades of health workers, was the next significant development in the history of health manpower education in this country. The formation of Kathmandu University (KU) and the starting of different categories of manpower too came next. TU too went ahead with its program of giving affiliation to many medical and dental colleges. During this interval, programs for the purpose of producing post graduates and super specialists in the field of medicine at the National Academy of Medical Sciences (NAMS) within the country was started. Dental programmes too were started by both KU and TU. The current tally of medical, dental and nursing colleges under the two universities are:

\begin{tabular}{|cccc}
\hline & MBBS & $\begin{array}{c}\text { Bachelor in } \\
\text { Dental Sciences }\end{array}$ & $\begin{array}{c}\text { BSc Nursing/ } \\
\text { Certificate Nursing }\end{array}$ \\
\hline KU & $7+(2)$ & 5 & $6 / 1$ \\
\hline TU & 7 & 5 & $6 / 0$ \\
NAMS & 0 & 0 & $0 / 1$ \\
\hline
\end{tabular}

Besides this, the government has started the Patan Academy of Health Sciences (PAHS), a deemed university which at present runs the MBBS program. The fourth $\mathrm{MoH}$ institution, the Karnali Academy of Health Sciences has still to function fully.There was at one time talk of having a medical college under the Purbanchal University also. Government assurance has been made regarding a Medical College each in the western and mid 
western region. Political commitment which has been made is that there will be a medical college in each of the seven provinces as envisioned by the promulgated constitution of Nepal. Such a decision is commendable in view of the fact that health is now a basic human right of the Nepalese. Will this put a stop to the practice of our leaders and 'High Ups' going to foreign countries for treatment? Media always carries news of absence of health personnel and lack of medicine plus equipment at the centres.

As far as nursing, ayurved and para medical education in the past were concerned, these were initially conducted by loM as extension programmes. Later, however, these and various other grades below 12 years of schooling were shifted to Centre for Technical Education and Vocational Training (CTEVT). The current medically related programs conducted under CTEVT are in eight categories: General Medicine, Nursing, Dental, Ayurveda. Medical Laboratory Technology, Ophthalmic Sciences, Pharmacy and Radiography.

What is a fact is that during the course of the last 20 years TU had given some sort of autonomy to IOM but now all this has been rescinded. Excessive pulling of strings has taken place in educational appointments too. With the starting of the different medical colleges in the country, many political and other forces have been attracted to this sector seeing chances of prompt benefits. Standards of medical education which should have been put in place have beenignored and bypassed. There are varying standards of teaching / learning in the medical, dental and nursing colleges scattered around in the country.

The call for the regulation of medical education has been going on for almost two decades. There was first the concept of having an 'apex body' to regulate medically related studies. Sometime later there were thoughts of the common entrance and final examinations for programmes of different universities. Both the Nepal Medical Council and the Nepal Nursing Council came up with more stringent rules and regulations for the training of students for their respective professions. However, there existed strong lobbies in Nepal to send students for these professions to countries surrounding us, with the allurements that it was very cheap out there in comparison to costs here. Agencies concerned took a hefty commission for their efforts.

What has come about now? Some measures have been taken by the different Nepali bodies concerned with the production of health manpower in our country. Attempts were made to put the criteria and requirements in order. There was the threat of dire action otherwise! It has to be understood that qualities of medical colleges have to be developed to be at par or even better than that of neighbouring countries. Faculty for the future were trained at various centres. Then the report of the Mathema Commission was tabled and subsequently comments on this were made by the Rai and Koirala bodies set up by the government.The actions being currently undertaken are said to be on these. A bill catering to essential requisites and realistic fulfilments of medical education requirements is said to be in parliament but the question remaining is whether sorting this out will be a priority at the time of national constitutional amendments.

The situation now is that medical colleges which prepared for these eventualities as per the Rules and Regulations of Nepal Medical Council ${ }^{2}$ are being left high and dry. Facilities which they created and employed for 150 students are being whittled down for hundred. Faculties trained specifically for Basic Science subjects are told to go elsewhere, irrespective of their bonds for service in the institution concerned. Non- medical faculty in Basic Sciences, who are the anchor for such study all over the world are being told to go elsewhere. Who is responsible for this fiasco? In such a situation will the colleges always have to acquire retired senior faculty from outside to be allowed to function?

However, having admitted 150 students for MBBS and different PG programs means that adequate clinical material is ensured. Regrettably, this is not so in many instances and the question arises if the students have had adequate exposure. It is claimed that institutions in foreign lands have many patients, but if the students cannot interact because of the language, then what is the use? Are the educational agencies still sending the students out of the country on false promises whilst the respective concerned councils or the government turn a blind eye?

Many talk of the 'Brain Drain' of trained medical, dental or nursing faculties to developed countries where the remunerations are much greater than in Nepal. Can one blame the new doctors or nurses, considering the expenditure entailed on their studies here? With all these factors are we ourselves going to be short of manpower to implement the proposed development of our own health services for our people? Are the locally trained doctors all going to be urban based for their private practise? Does not the Nepali populace deserve better health services? Is the dream of Medical Tourism in Nepal just a mirage? 
Voices for setting up a Health Sciences / Medical University have been in the air in Nepal for some time. This concept is being implemented in India and some of provinces there e.g. Tamil Nadu, Haryana already boast of one. Even during the time that Dr. Ram Baran Yadav was President of Nepal, some voices had been heard regarding the setting up of a Medical University in Nepal with which all the colleges teaching subjects allied to healing could be aggregated together. Sadly, this has not occurred till now, but should be seriously considered. A large number of Nepali students are going out of Nepal to Bangladesh, China, India, Philippines and even further afield for study in these fields. A lot of the foreign exchange, that has come in as remittance by hard working Nepali labour in Gulf countries or Malaysia is being used for this purpose. All this could be saved and students trained within the country if planning was done right. Enhancing the standards of medical/health related colleges providing education and training to future generations of workers to provide patient care in the hospitals of the country would ultimately benefit the patient who we all strive to care for.

\section{REFERENCES}

1. Dixit H. Nepal's Quest for Health. Fourth edition. Educational Publishing House, Kathmandu, Nepal, 2014.

2. Nepal Medical Council. NMC Guidelines. Nepal Medical Council. Kathmandu, 2013. 